\title{
ACTIVATED PROTEIN C RESISTANCE, ENDOGENOUS ANTICOAGULANTS AND COAGULATION PARAMETERS IN RECURRENT PREGNANCY LOSS
}

\author{
Gokalp ONER $^{1}$, Iptisam Ipek MUDERRIS ${ }^{1}$, Cetin SAATCI $^{2}$ \\ ${ }^{1}$ Department of Gynecology and Obstetric, Faculty of Medicine, Erciyes University, Kayseri, Turkey \\ 2 Department of Genetics, Faculty of Medicine, Erciyes University, Kayseri, Turkey
}

\begin{abstract}
SUMMARY
Objective: Recurrent miscarriage is usually defined as three or more consecutive miscarriages before 20 weeks and it occurs in $0.5 \%-1 \%$ of total pregnancies. Therefore, activated protein $C$ resistance (APCR), protein C and $S$ deficiency, antithrombin deficiency is important pathologies for RPL. In this study, our aim was to assess the role of thrombophilia parameters in RPL.

Material and methods: 35 patients with RPL and 53 healthy control withot RPL were included in this study. Exclusion criterias of this study were uterin anomalies, chronic systemic disease, antiphospholipid and anticardiolipin antibodies entity that caused RPL.

Results: There was no difference between two groups for ages. The mean pregnacy loss of 35 patients with RPL was $3.57 \pm 1.54$ (3-11 items). When patients were compared for the APC resistance, there was a significant difference between the groups. Although the values of protein C, protein S and antithrombin III were low, there was no statistically significant difference between groups.

Conclusion: Thrombophilia including APC resistance, protein C and $S$ deficiency, antithrombin deficiency is associated with RPL. Thrombophilia is consequential for the prognosis of pregnancy and is considered for the following of pregnancy in patients with pregnancy.
\end{abstract}

Key words: habitual abortion, thrombophilia

Journal of Turkish Society of Obstetrics and Gynecology, (J Turk Soc Obstet Gynecol), 2011; Vol: 8 Issue: 4 Pages: $244-8$

\section{TEKRARLAYAN GEBELIKK KAYBINDA AKTIVE PROTEiN C DİRENCI, ENDOJEN ANTIKOAGÜLANLAR VE KOAGULASYON PARAMETRELERİ}

ÖZET

Amaç: Yirminci gebelik haftasından önce üç veya daha fazla tekrarlayan abortus öyküsü olarak tanımlanan tekrarlayan gebelik kaybı (TGK), reproduktif yaşlarda olan tüm kadınların \%1-5 kadarında görülmektedir. Bu yüzden aktive protein C rezistansı (APCR), protein C ve S eksikliği, antitrombin eksikliği gibi maternal trombofililer, TGK açısından önemli patolojilerdir. Biz bu çalışmada TGK'da trombofili parametrelerinin rolünü ortaya koymaya çalıştık. Gereç ve yöntemler: Bu çalışmaya TGK olan 35 hasta ve hiçbir düşüğü olmayan sağlıklı 53 kontrol hastası dâhil edildi. Çalışmaya dâhil edilmeme kriterleri arasında; TGK'na neden olabilecek uterin anomali varlığı, kronik sistemik hastalık varlı ̆̆l, antifosfolipid ve antikardiyolipin antikorları varlığı kabul edildi.

Bulgular: Her iki grupta yaşlar açısından fark yoktur. TGK olan 35 hastanın ortalama düşük sayısı $3.57 \pm 1.54$ (311 tane) idi. Hastalar APC direnci oranları açısından karşılaştırıldı̆̆ında tekrarlayan gebelik kaybı olan hastalarla

Address for Correspondence: Gökalp Öner. Erciyes Üniversitesi Tıp Fakültesi, 38039 Kayseri.

Phone: + 90 (506) 2346822

e-mail: onerg@yahoo.com

Received: 06 December 2010, revised: 18 March 2011, accepted 11 August 2011, online publication: 23 August 2011 
kontrol grubu arasında anlamlı fark bulunmaktadır (p=0.028). Her iki grup karșılaștırlldığında protein C, protein $S$ ve antitrombin III seviyeleri düşük olmalarına rağmen aralarında istatistiksel anlamlı fark yoktur.

Sonuç: APC direncini, protein C ve S eksikliğini ve antitrombin III eksikliğini içeren trombofililer TGK ile ilişskilidirler. TGK olan hastalarda trombofili boyutu gebeliğin prognozunda önemli yer tutmaktadır ve gebelik takibinin tedavisinde dikkate alinmalıdir.

Anahtar kelimeler: tekrarlayan düşük, trombofili

Türk Jinekoloji ve Obstetrik Derneği Dergisi, (J Turk Soc Obstet Gynecol), 2011; Cilt: 8 Sayl: 4 Sayfa: 244- 8

\section{INTRODUCTION}

Recurrent pregnancy loss (RPL) is defined as three or more consecutive pregnancy losses prior to 20 weeks of gestation or less than 500 gram of fetus weight and occurring in $\% 0.5-1$ of all pregnancies ${ }^{(1)}$. The abortus rate of the next pregnancy in a woman who has a spontaneous abortus is approximately $\% 20$; after three miscarriages, this rate increased up to $\% 50^{(2)}$. The causes of abortus is various and mostly unknown. A lot of reasons exhibit to explain the etiology of RPL. These are genetic, anatomic, endocrinological factors, placental abnormalities, infections, consumption of cigarette and alcohol, different environmental factors (ionizing radiation, consumption of chemical agent), and stress(3).

Recently, thrombophilias become important in the etiology of RPL. Although investigations were made in unknown or unexplained cases of RPL, there were no reasons in most cases. In these cases, there were positive alive pregnancy rates to use low molecular weight heparin (LMWH) or aspirin ${ }^{(4)}$. Thus, the cause of thrombosis does not depend on one factor or the etiologic tests do not explain all reasons ${ }^{(5)}$.

Activated protein $\mathrm{C}$ resistance (APCR) is the most prevalent reason of hereditary thrombophilias. The most common inherited thrombophilic disorder is mutation which consisted of a single point mutation resulting in replacement of amino acids arginine by glutamine at position 506 in factor $\mathrm{V}$ gene that is called factor V Leiden (FVL). This resists the factor $\mathrm{Va}$ protein against the inactivation of APC. The approximate frequency of this mutation in the population changes between $\% 2-7$ and it is approximately \% 20-50 responsible for inherited thrombophilias and cases with thrombosis. APCR development depends on increasing factor $\mathrm{V}$ and VIII and decreasing the values of free Protein $\mathrm{S}^{(6)}$.

The natural anticoagulants such as antithrombin III (AT III) inactivate the activated factor X, IX, XII and especially thrombin. Although there was no important change in the levels of AT III in the pregnancy, there was a decrease in the levels in the delivery and postpartum one week ${ }^{(7)}$.

Procoagulation proteins such as Factor V and Factor VIII were inactivated by fragmenting with the natural anticoagulant Protein C. Protein S is a cofactor of Protein S. Although Protein C is constant or slight increase in pregnancy, Protein $\mathrm{S}$ decreases in an important meter ${ }^{(8)}$. During pregnancy, there was a new balance to occur thrombus because of the dominance of procoagulants to anticoagulants.

For a successful pregnancy, there must be an effective uteroplacental circulation and this circulation may affect from the deficiencies of hemostases. Therefore maternal thrombophilias such as APCR, Protein C, S and antithrobin deficiencies are pivotal pathologies for obstetrical view. In this study, we tried to show the role of thrombophilia in RPL.

\section{MATERIAL AND METHODS}

This study included 35 women with RPL and 53 control patients who were in the same age group and had a history of successful pregnancy without any individual, familial or systemic disease between the years of 2006 and 2007.

The exclusion criteria were accepted as uterine anomalies leading to RPL, chronic systemic disease, and existence of antiphospholipid and anticardiolipin. There was no difference between the study and control group for the age.

Patients included this study were informed and informed consent was obtained from all patients. Demographical features of patients, the number of abortus, the weeks of RPL, and the history of thrombosis and family were recorded. Venous blood samplings were collected by tubes with Nacitrate-EDTA from women of the patient 
and control group. Two cc blood samples for Protein C, Protein S and AT III were chromogenically studied in the biochemical laboratories of Erciyes University.

In this prospective designed study, normally or nonnormally distributed groups were compared with Student-T and Mann-Whitney U tests. Additionally the values were written as means \pm standard deviations. All analyses were performed using SPSS 15.0.

\section{RESULTS}

The mean of the patients was $27.89 \pm 5.66$ in control group and $28.71 \pm 5.64$ in case group and there was no statistically difference between two groups $(p=0.50)$. There were statistically significant differences between the groups for pregnancy, parity, abortus and alive baby $(p<0.001)$. The mean of thirty five patients with RPL was $3.57 \pm 1.54$ (min-max; 3-11). When the group with RPL compared with control group, there was a statistically significant difference for the coagulation parameters including activated partial thromboplastin time (APTT) and prothrombin time $(\mathrm{p}=0.029$ and $\mathrm{p}<0.001)$, but there was no difference for international normalized ratio (INR) $(p=0.83)$. There was no difference for other coagulation parameters, $d$-dimer, and fibrinogen $(p>0.05)$. There was significant difference between control and RPL groups for APCR $(p=0.028)$. Although the values were low, there was no statistically significant difference comparing two groups for Protein $\mathrm{C}(\mathrm{p}=0.45)$, Protein $\mathrm{S}(\mathrm{p}=0.19)$ and AT III ( $\mathrm{p}=0.21)$ (Table I).

Table 1: Demographical properties of patients, APCR, endogenous anticoagulant and coagulation parameters.

\begin{tabular}{llll}
\hline & Case group & Control group & P \\
& $\mathbf{3 5}$ & $\mathbf{5 3}$ & \\
\hline Age (year) & $28.71 \pm 5.64$ & $27,89 \pm 5.66$ & $>0.05$ \\
Pregnancy & $3.88 \pm 1.89$ & $2.28 \pm 1.27$ & $<\mathbf{0 . 0 0 1}$ \\
Parity & $0.51 \pm 0.98$ & $1.08 \pm 1.05$ & $<\mathbf{0 . 0 0 1}$ \\
Abortus & $3.57 \pm 1.53$ & $0.30 \pm 0.57$ & $<\mathbf{0 . 0 0 1}$ \\
Alive baby & $0.31 \pm 0.63$ & $1.07 \pm 1.05$ & $<\mathbf{0 . 0 0 1}$ \\
APTT & $29.82 \pm 3.78$ & $28.89 \pm 5.04$ & $\mathbf{0 . 0 2 9}$ \\
PT & $12.43 \pm 1.00$ & $11.56 \pm 1.14$ & $<\mathbf{0 . 0 0 1}$ \\
INR & $0.91 \pm 0.21$ & $0.96 \pm 0.09$ & $>0.05$ \\
D-Dimer & $0.82 \pm 0.23$ & $1.27 \pm 0.81$ & $>0.05$ \\
Fibrinogen & $399.09 \pm 81.79$ & $477.76 \pm 108.24$ & $>0.05$ \\
Activated protein & & & \\
C resistance & $2.37 \pm 0.81$ & $2.08 \pm 0.60$ & $\mathbf{0 . 0 2 8}$ \\
Protein C \% & $116.54 \pm 24.23$ & $120.45 \pm 23.66$ & $>0.05$ \\
Protein S \% & $93.64 \pm 43.07$ & $81.16 \pm 35.68$ & $>0.05$ \\
Antithrombin III \% & $101.55 \pm 19.45$ & $107.10 \pm 20.62$ & $>0.05$ \\
\hline & & &
\end{tabular}

J Turk Soc Obstet Gynecol 2011; 8: 244- 8
Thirty five patients with RPL had 5 patients with APCR (\% 14), 2 patients with Protein S deficiency (\% 5), 1 patient Protein $\mathrm{C}$ deficiency (\%3). None of them had AT III deficiency.

\section{DISCUSSION}

The probable reasons of RPL are genetic factors (structural or numerical anomalies, single gen defects, translocation carrier, inversions, etc. \% 3-5), endocrine factors (luteal phase deficiency, polycystic ovary syndrome, diabetes mellitus, hyperprolactinemia, thyroid auto antibodies or thyroid diseases, etc. \% 1560 ), uterine causes (uterine anomalies, myoma uteri, cervical insufficiency, uterine adhesions, etc. \% 1050), immunological factors (antiphospholipid antibody syndrome, allogenic factors, etc. \% 5-15), thrombophilic disorders (hereditary thrombophilias such as FVL mutation, prothrombin gene mutation, deficiencies of Protein C, S or AT III, etc.), environmental factors (cigarette smoking, anesthesical reagent exposure, etc), and ovarian reserve defects. However, in most of cases, there were no etiologic factors ${ }^{(9-10)}$.

Thrombophilias might be hereditary or acquired. AT III was firstly noticed then Protein C and Protein S were announced as hereditary thrombophilia reasons in order(11). These three reasons may be responsible for $\% 5-15^{(12)}$. In 1993, Dahlback et al. showed that plasma samples of patients with hereditary thrombophilia resisted against the anticoagulant effect of APC (13). Hereditary thrombophilias such as APCR, Protein $\mathrm{C}$ and $\mathrm{S}$ deficiencies are mostly responsible for RPL ${ }^{(14)}$. Their effects on coagulation pathway were summarized in Table II.

Table II: Schematic view of coagulation parameters.

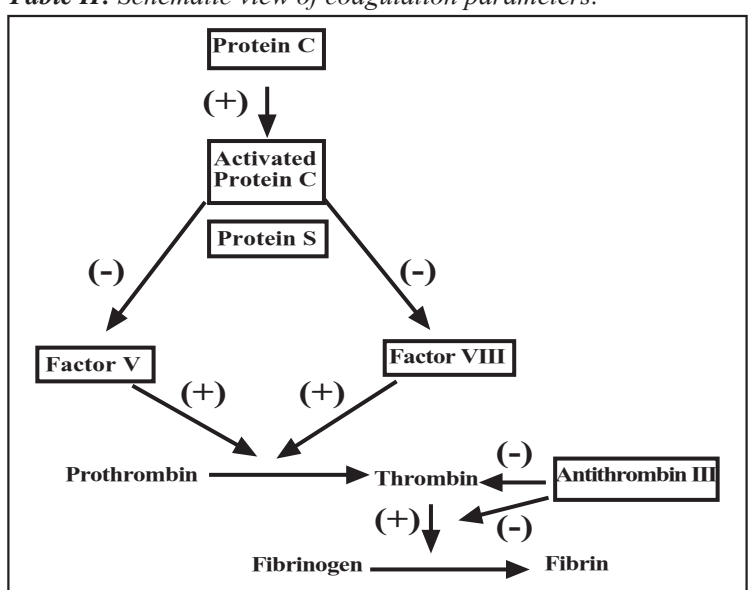


In the year of 1994, it was understood that APCR may depend on a point mutation in the gene of Factor $\mathrm{V}$ and this mutant gene was named as FVL. Although FVL is the most common reason for APCR, it is not unique cause. The patients with APCR are $\% 90$ positive with FVL mutation ${ }^{(15)}$. Moreover, APCR is the most common reason for hereditary thrombophilias and covers $\% 20-50$ of cases ${ }^{(16-18)}$. In another study about RPL, 34 of 184 patients had isolated $\mathrm{APCR}^{(19)}$. In our study, this rate is approximately \% 14 and this rate is compatible with literature.

The prevalence of AT III deficiency in the community varied between 1/2000-1/5000. Hereditary AT III deficiency is autosomal dominant and most of cases are heterozygote $(20,21)$. In our study, there was no patient with AT III deficiency. Protein C was synthesized from liver and was changed to serine protease anticoagulant activity by thrombin ${ }^{(22)}$. Its incidence is $1-5 / 1000$. Protein C deficiency is autosomal dominant ${ }^{(23)}$. When the relation between fetal loss and hereditary thrombophilic disorder was examined, the women with combined deficiency and AT III deficiency had increased risk for obstetrical problems such as stillbirth $^{(24)}$. In our study, 35 patients with $>2$ RPL and healthy 53 control women were included. There was no statistically significant difference for ages of two groups.

APCR was measured in plasma with APTT based methods using with or without activated protein $\mathrm{C}^{(25)}$. These methods are easy and cheap. It is sensitive both APCR Syndrome and FVL mutation. FVL mutation covers most of APCR cases in fact not at all. In another possibility, APTT based methods were applied in test plasma with FV absent plasma after dilution. In our study, APTT was increased in RPL group; this might be the result of increased APCR ratio in this group.

APCR is related with miscarriages, intrauterine growth retardation and fetal loss $(25,26)$. There was a positive relation between RPL and Protein C, Protein S or AT III deficiencies ${ }^{(27)}$. Prophylactic LMWH usage in RPL cases with thrombophilia is related with increased pregnancy outcomes ${ }^{(28,29)}$. However, aspirin usage in RPL does not affect pregnancy outcomes according to all meta-analysis and case-control studies ${ }^{(30)}$. Preston et al. exhibited that thrombophilia positive patient from 843 RPL patients had increased risk comparing with $\operatorname{control}^{(8)}$.
In our study, there were significant thrombophilia positive patients in RPL than control and the knowledge of thrombophilia is important to plan and follow next pregnancy. There are lots of studies for thrombophilia and RPL and their results are controversial. But our study indicated that thrombophilia in patients is pivotal for the prognosis of pregnancy and it might be considered for following of pregnancy.

\section{REFERENCES}

1. Baek KH, Lee EJ, Kim YS. Recurrent pregnancy loss: the key potential mechanisms. Trends Mol Med. 2007; 13: 310- 7.

2. Regan L, Braude PR, Trembath PL. Influence of past reproductive performance on risk of spontaneous abortion. BMJ. 1989; 299: 541- 5 .

3. Kutteh WH. Recurrent pregnancy loss: an update. Curr Opin Obstet Gynecol 1999; 11: 435- 9.

4. Clifford K, Rai R, Regan L. Future pregnancy outcome in unexplained recurrent first trimester miscarriage. Hum Reprod 1997; 12: 387- 9 .

5. Sambrano GR, Weiss EJ, Zheng YW, Huang W, Coughlin SR. Role of thrombin signalling in platelets in haemostasis and thrombosis. Nature 2001; 413: 74- 8 .

6. Mc Coll, Walker G. The role of inherited thrombophiliain venous thromboembolism associated with pregnancy. B J Obstet Gynaecol, 1999; 106: 756- 66.

7. Letsky EA, Swiet M, Loscalzo J, Schafer AI. Maternal hemostasis coagulation problems of pregnancy in; Thrombosis and Hemorrhage. Blackwell Scientific Publications, 1994; 965- 98 .

8. Preston FE, Rosendaal FR, Walker ID, Briët E, Berntorp E, Conard J, et. al. Increased fetal loss in women with heritable thrombophilia. The Lancet, 1996; 348: 913- 6.

9. Carrington B, Sacks G, Regan L. Recurrent miscarriage: Pathophysiology and outcome. Curr Opin Obstet Gynecol 2005; 17: 591- 7 .

10. Kujovich JL. Thrombophilia and pregnancy complications. Am J Obstet Gynecol 2004; 191: 412- 24.

11. Booto LD, Yang Q. 5,10- methylenetetrahydrofolate reductase gene variants and congenital anomalies. Am J Epidemiol, 2000; 151: 862- 77 .

12. Martinelli M, Scapoli L, Pezzetti F, Carinci F, Stabellini G. C677T variant form at the MTHFR gene and CL/P:a risk factor for mothers? Am J Med Genet, 2001; 98: 357- 60 .

13. Brenner B, Mandel H, Lanir N, Younis J, Rothbart H, Ohel G, Blumenfeld Z. Activated protein C resistance can be 
associated with recurrent fetal loss. Br J Haematol, 1997; 97(3): 551- 4

14. Girling J, de Swiet M. Inherited thrombophilia and pregnancy. Curr Opin Obstet Gynecol 1998; 10: 135- 44.

15. Aubard Y, Darodes N, Cantaloube M. Hyperhomocysteinema and pregnancy review of our present understanding and therepeutic implications. Eur J Obstet Gynecol, 2000; 93: 157- 65 .

16. Kutteh WH, Park VM, Deitcher SR. Comment in: Hypercoagulable state mutation analysis in white patients with early first-trimester recurrent pregnancy loss. Fertil Steril, 1999; 71(6): 1048- 53.

17. Rai R, Regan L. Thrombophilia and adverse pregnancy outcome. Semin Reprod Med, 2000; 18(4): 369- 77.

18. Greer IA. Thrombophilia: implications for pregnancy outcome. Thromb Res. 2003; 109: 73- 81.

19. Younis JS, Brenner B, Ohel G, Tal J, Lanir N, Ben-Ami M. Activated protein $\mathrm{C}$ resistance and factor $\mathrm{V}$ Leiden mutation can be associated with first-as well as second-trimester recurrent pregnancy loss. Am J Reprod Immunol. 2000; 43: 31- 5.

20. Mills JL, Kirke PN, Molloy AM, Burke H, Conley MR. Methylenetetrahydrofolate reductase Thermolabile variant and oral clefts. Am J Med Genet, 1999; 86: 71- 4.

21. Richard E, Bonnette, Marie A, Caudıll, Anıta M, Boddie. Plazma homocysteine concentrations in pregnant and nonpregnant women with controlled folate intake. Obstet Gynecol, 1998; 92: 167- 70.
22. Richard E, Bonnette, Marie A, Caudıll, Anıta M, Boddie. Plazma homocysteine concentrations in pregnant and nonpregnant women with controlled folate intake. Obstet Gynecol, 1998; 92: 167- 70.

23. Mills JL, Kirke PN, Molloy AM, Burke H, Conley MR. Methylenetetrahydrofolate reductase Thermolabile variant and oral clefts. Am J Med Genet, 1999; 86: 71- 4.

24. Blumenfeld Z, Brenner B. Thrombophilia-associated pregnancy wastage. Fertil Steril, 1999; 72: 765- 74.

25. Sedano S, Gaffney G, Mortimer G, Lyons M, Cleary B, Murray M, et al. Activated protein C resistance (APCR) and placental fibrin deposition. Placenta. 2008; 29: 833- 7.

26. Dogan Y, Has R. Pregnancy and thrombophilia. Turkiye Klinikleri J Gynecol Obst-Special Topics 2010; 3: 64- 9.

27. Sanson BJ, Friederich PW, Simioni P, Zanardi S, Hilsman MV, Girolami A, et al. The risk of abortion and stillbirth in antithrombin-, protein C-, and protein S-deficient women. Thromb Haemost. 1996; 75: 387- 8.

28. Mantha S, Bauer KA, Zwicker JI. Low molecular weight heparin to achieve live birth following unexplained pregnancy loss: a systematic review. J Thromb Haemost. 2010; 8: 2638.

29. Rotmensch S, Liberati M, Mittlemann M, Ben-Rafael Z. Activated protein $\mathrm{C}$ resistance and adverse pregnancy outcome. Am J Obstet Gynecol. 1997; 177: 170- 3.

30. Rai R, Regan L. Recurrent miscarriage. Lancet. 2006; 368: 601- 11 . 